select committee was essential if the opposers of the Bill were to make their case and be challenged on it.

Lord Molson agreed, and said that if the Bill received a second reading, he would move a special instruction to the select committee that it consider the need to supply water at all, other sites for reservoirs, and other methods of supplying water. Imperial Chemical Industries, Ltd., he said, was prepared to make a grant of $£ 100,000$ for a crash programme of research before the area was submerged, but it would be better to wait for the report of the Water Resources Board which was still investigating. In any event, the price that ICI was paying for water ( $1 s .1 d$. a thousand gallons) was well below the national average of $3 s$. a thousand gallons. That margin, said Lord Molson, gave ICI an ample opportunity to pay a higher price for a reservoir at Middleton in Teesdale and thus to preserve the amenities of Upper Teesdale.

The Earl of Swinton announced that he was a native of the region, and visited it regularly. He had at first been horrified by the proposals, but had since discovered that none of the flowers of which he was fond was to be submerged. He had tried to find out whether grouting would be necessary over a wide area, but his latest information indicated that it would only be necessary within the area of the reservoir itself. But Lord Hurcomb disagreed. Lord Swinton's opinions were not impartial. Why, Lord Hurcomb asked, was the opposition so determined? It was because the site was of exceptional scientific importance; the promoters of the Bill had gone too far in their attempt to write this off. The issue was not one of a few flowers; Upper Teesdale contained a unique community of relict flora which was irreplaceable. If, as the Water Board claimed, Cow Green was the next logical step, what was the next logical step after that ? If the answer was to build a reservoir at Middleton in Teesdale, why did the Board not do it at once?

But in the end the Bill was read for a second time. Obviously the select committee will be fun.

\section{Indian Research}

THE rapid growth of science and scientific research in India has imposed a need for planning and organization. Effective planning needs accurate and up to date information, which in India is the responsibility of the Research Survey and Planning Organization of the Council of Scientific and Industrial Research. The second annual report of the organization defines its responsibilities under three headings-survey and planning of research, operational research and international scientific collaboration.

of these, the most important is the survey work of the organization. Scientific societies, industrial research laboratories, research institutes, and the Indian universities have all been studied. Collaboration between industrial laboratories and research institutes is increasing, but the report criticizes the universities for isolating themselves from other centres of research, and for concentrating on the more familiar branches of science at the expense of newer fields. The high mortality rate among Indian scientific journals is to be studied; this may perhaps be related to the precarious financial position of many of the learned societies which publish the journals. An opinion poll carried out by the organization shows that Indian scientists are frustrated by poor service conditions, and by the feeling that the control of science is in the hands of bureaucrats; many feel that the situation would be improved if more scientists and technologists were involved in the administration of science.

As far as the expenditure of the Indian Government on research is concerned, the report paints a depressing picture. Although expenditure has increased, the increases have not been significant in real terms, for the number of scientists has increased more rapidly; in particular the growth of expenditure on auxiliary facilities such as workshops and libraries has been far too slow. Foreign aid agencies, the report suggests, are uncoordinated, tend to give grants only for specific topics, and spend too much on foreign experts.

Financial stringency is also a limitation on the programme of international scientific collaboration. To some extent this difficulty can be overcome by bilateral exchange agreements, a number of which have been negotiated; the agreement with Britain, for example, provides for fifteen Indian scientists to come to Britain each year, in exchange for six British scientists. It would seem, however, that this programme is not being fulfilled, as only three Indians visited Britain last year, in exchange for two British scientists.

\section{Cast Iron Uncertainty}

The British Cast Iron Research Association finds itself in a peculiar position. The main financial support for its work over the past 18 years has come from the Pig Iron Levy Fund, contributions to which were made on a compulsory basis by iron founders buying pig iron in the United Kingdom. The fund was felt to be inequitable, however, because not all the users of the association's services were contributors; some, like Ford Motors, make their own pig iron, while others buy it from overseas. Imports of pig iron have risen over the past three years from 30,000 to 400,000 tons a year, which has caused the receipts from the fund to decline. Much of the association's work is in any case designed to achieve a greater use of scrap, at the expense of pig iron; the more successful this aspect of the work became, the less the association could expect from the Levy Fund.

But two appeals to the membership for voluntary support were unsuccessful, so that the Iron and Steel Board asked the Ministry of Power to introduce a statutory levy, which came into operation on July 1, 1966. British members who pay this levy are entitled to the full range of the services offered by the association, except routine analysis or detailed consultation for which they must pay more.

The statutory levy seems a good idea in principle, even if its introduction was somewhat undignified. Unfortunately, it is unlikely to be in force for long enough for the association to decide if it likes it, for as the nationalization of the steel industry will absorb the Iron and Steel Board, new arrangements for financing the association will have to be devised.

The research work of the association is a good deal clearer than its financial situation. The work has covered the whole range of iron founding; particularly interesting are developments in the control and instrumentation of foundry practice. It is hoped that the electrical and magnetic properties of liquid cast iron can be studied by rapid electronic means to give information about the material before it is actually cast. 